Etnolingual Vol 3 No 1

Mei, 2019, 27-41

\title{
CONJUNCTIONS IN INDONESIAN UNDERGRADUATE THESIS ABSTRACTS
}

\author{
Ruri Fadhilah Kurniati \\ rurifadhilah@gmail.com \\ Universitas Teknologi Surabaya
}

\begin{abstract}
This study investigates how conjunctions are used for organizing ideas in abstracts of linguistics and literature theses written by undergraduate students of English Department in an Indonesian university. It also reveals the similarities in the ways conjunctions being used in the abstracts. It employs descriptive qualitative design to examine 82 abstracts which have been collected from 41 linguistics and 41 literature theses. The abstracts are analyzed by classifying and calculating the use of conjunctions using conjunctions taxonomy proposed by Halliday and Matthiessen (2014). The study finds that six abstracts do not apply conjunctions. While the rest show a high frequent use of the three types of conjunctions: elaboration, extension, and enhancement. Elaborating conjunctions are used appropriately, whereas extending and enhancing conjunctions are partly inappropriately. Two kinds of inappropriate uses of conjunctions are misuse and overuse. The use of conjunctions in abstracts of linguistics and literature theses is quite similar in the ways they are used and the total number of their uses. Certain conjunctions are present in the abstracts, while the others are inexistent. Both kinds of abstracts mostly use extending conjunctions, more especially positive additives. It can be concluded that the use of conjunctions varies in terms of their appropriateness. Inappropriate uses of conjunctions prove that EFL (English as a foreign language) learners had difficulty in using conjunctions in their writing. The students whose abstracts do not apply conjunctions connected the ideas in their abstracts using words and/or phrases which are excluded in the theoretical framework of this study. More similarities than differences in the ways conjunctions being used in the two kinds of abstracts prove that students from the same department of the study had the same discourses.
\end{abstract}

Keywords: conjunctions, abstracts, linguistics theses, literature theses

\begin{abstract}
Abstrak
Penelitian ini meneliti penggunaan konjungsi untuk penyusunan gagasan pada abstrak skripsi linguistik dan sastra karya mahasiswa jurusan S1 Sastra Inggris di sebuah universitas di Indonesia. Penelitian ini juga menganalisa kemiripan penggunaan konjungsi pada kedua jenis abstrak. Penelitian ini mengaplikasikan desain penelitian kualitatif deskriptif. Sumber data adalah 82 abstrak yang diperoleh dari 41 skripsi linguistik dan 41 skripsi sastra. Analisa data dilakukan dengan mengklasifikasi dan mengalkulasi penggunaan konjungsi pada abstrakabstrak tersebut dengan menggunakan teori konjungsi Halliday dan Matthiessen (2014). Penelitian ini menunjukkan bahwa enam abstrak tidak menggunakan konjungsi. Abstrakabstrak lainnya menggunakan ketiga tipe konjungsi: elaboration, extension, dan enhancement. Elaboration digunakan secara tepat, sedangkan beberapa extension dan enhancement tidak tepat. Dua macam ketidaktepatan penggunaan konjungsi yaitu kesalahan penggunaan dan penggunaan berlebihan. Penggunaan konjungsi pada abstrak skripsi linguistik dan sastra menunjukkan banyak kemiripan pada pemilihan dan jumlah penggunaannya. Konjungsi tertentu ditemukan pada abstrak-abstrak tersebut, sedangkan yang lainnya tidak ditemukan sama sekali. Kedua jenis abstrak menggunakan konjungsi extension paling banyak, terutama positive additive. Berdasarkan hasil penelitian dan tafsirannya, dapat disimpulkan bahwa ketepatan penggunaan konjungsi bervariasi. Ketidaktepatan penggunaan konjungsi memperlihatkan bahwa pemelajar Bahasa Inggris sebagai bahasa asing mengalami kesulitan dalam menggunakan konjungsi pada tulisan mereka. Beberapa mahasiswa yang tidak menggunakan konjungsi pada abstraknya menghubungkan gagasan menggunakan kata dan/atau frase yang tidak termasuk dalam kerangka teori pada penelitian ini. Lebih banyak
\end{abstract}


kemiripan daripada ketidakmiripan dalam penggunaan konjungsi pada kedua jenis abstrak membuktikan bahwa mahasiswa dari jurusan yang sama memiliki diskursus yang sama.

Kata Kunci: konjungsi, abstrak, skripsi linguistik, skripsi sastra

\section{INTRODUCTION}

Abstract of a thesis or other types of writing is highly valued since it highlights the content of the text. It provides readers with any essential points of the whole thesis. The abstract is a brief summary of the entire study (McMillan, 2008). Moreover, in the information era, the prevailing usage of online publication database calls for wellconstructed and informative abstracts because many search engines for academic purposes only show the abstracts (Cheng, 2014). Even for any studies that are not published online, an abstract always comes into the first view of the academic writings, performing as the entry point for the texts. This consequently forces students to try their utmost to compose meaningful, logical and clarified abstracts for their theses (Cheng, 2014).

In creating a thesis' abstract, students should pay attention to the contents. The most common structure for an abstract is a four-part arrangement consisting of problem, method, results, and conclusions (Graetz, cited in Swales, 1990). Another standard structure of abstract is normally background position, aim, and thesis of article, method of research, and results of research (Bailey, 2011). It is obvious that an abstract is full of crucial information. There are several ideas that should be written clearly and completely in order to accomplish the general structure of the abstract. The shift from an abstract's message to another should be smooth and apparent. In terms of organization of the ideas, conjunctions are needed which concerned with transitions between whole 'messages' (Halliday \& Matthiessen, 2014). Accordingly, students should be able to apply conjunctions in organizing their abstract.

Conjunction as one of the types of English cohesion has aroused researchers' interest, for instance, Ketabi and Jamalvand (2012) and Hamed (2014). Ketabi and Jamalvand (2012) identified conjunction devices in English international law texts and its Farsi translation. The finding showed that both ELTs and FTTS share more similarities than differences in the use of conjunctions. The common cohesive devices are maintained in Farsi translation for precision, clarity, and logicality. Hamed (2014) examined the utilization of conjunctions in argumentative essays written by Libyan undergraduates majoring in English at Omar Al-Mukhtar University. His study confirmed that the Libyan EFL undergraduates used the conjunctions improperly and that the adversative conjunctions were the most complex for the students, followed by additives and causals. The findings of his study verified prior studies that EFL learners have complexity in utilizing conjunctions in their writing. However, their researches do not examine the utilization of conjunctions in abstracts of academic writings. The present study observes the use of conjunctions in undergraduate thesis abstracts. 
There have also been studies in relation to abstracts of academic writings, for example, Jeon and Eun (2007) and Cheng (2014). Jeon and Eun (2007) analyzed doctoral dissertation abstracts written by American and Korean writers from the standpoint of contrastive rhetoric. They did not find any significant difference between the macro-structure in both abstracts. Abstracts by Korean writers are much longer than those of American writers. The reasons for the use of passive voice are different; American writers for cohesion, whereas Korean for objectivity. Concerning referential expressions, writers' use of 'this, these' more than 'that, those' indicated that writers feel their dissertation psychologically near. Cheng (2014) investigated three types of cohesive devices, that is, reference, conjunction, and lexical cohesion, in English abstracts of MA Theses in Chinese and occidental on the basis of Halliday and Hasan's (1976) cohesion theory. His study found that cohesive devices used in abstracts are typical, in which lexical cohesion is dominant, and then reference and conjunction follow. His next finding pointed out that dissimilarities between sources of texts are more significant than those between the groups of subjects. Chinese students' usage of cohesive devices, especially lexical cohesion, is considerably dissimilar than those of the occidental ones. The Chinese students, particularly those from computer science, demonstrated restricted selections of lexical cohesion and met difficulties in employing reference and conjunction when writing abstracts. Different from their studies, this existing study examines the use of conjunctions and focuses on the examination only on conjunctions to obtain a deep analysis.

Grounded in the rationale and motivation above, it is requisite to conduct research on the Indonesian context of students' theses to investigate the conjunctions. The present study scrutinizes the use of conjunctions in abstracts of linguistics and literature theses written by undergraduate students of English Department. The interest lies in potential differences and commonalities in the use of cohesive devices across the discipline of texts (Cheng, 2014). The writer wonders if linguistics and literature theses, whose writers are from the same department of study, share differences and/ or similarities in the abstracts. In this study, the investigation of cohesive devices is focused only on the use of conjunctions, that is, disregarding other types of cohesion because the study aims at exploring the regularity in shifting ideas/messages in the abstracts and gaining an in-depth analysis and interpretation of the data.

Specifically, the purposes of the study are (1) to explain how conjunctions are used for organizing ideas in abstracts of linguistics and literature theses written by undergraduate students of English Department and (2) to reveal similarities in the ways conjunctions being used in abstracts of linguistics and literature theses written by undergraduate students of English Department.

\section{THEORETICAL FRAMEWORK}

Conjunctions theory proposed by Halliday and Matthiessen (2014) is used as 
the theoretical framework in this study to analyze and interpret the data. A conjunction is concerned with rhetorical transitions - transitions between whole 'messages', or even message complexes (Halliday \& Matthiessen, 2014). It is a resource for marking a transition in the unfolding of a text (Halliday \& Matthiessen, 2014). It indicates the relations through which such textual transitions are created.

Conjunctive elements are cohesive not in themselves but indirectly by virtue of their specific meanings; they are not primarily devices for reaching out into the preceding (or following) text, but they express certain meanings which presuppose the presence of other components in the discourse (Halliday \& Hasan, 1976, p. 226). In a simpler description, the term conjunction refers to words such as and, but, however, finally, then, and in conclusion that join phrases, clauses, or sections of a text in ways that express their logical-semantic relationship (Paltridge, 2000). The logical-semantic relationship of conjunctions is explained further in the subsequent paragraph.

The cohesive system of conjunction has evolved as a complementary resource for creating and interpreting text (Halliday \& Matthiessen, 2014). It provides the resources for marking logico-semantic relationships that obtain between text spans of varying extent, ranging from clauses within clause complexes to long spans of a paragraph or more. Cohesive conjunctions may be used within clause complexes, between two clause complexes, link to part of an earlier clause complex, and link domains that are more extensive than single clause complexes.

Halliday and Matthiessen (2014) categorize conjunction into three types: elaboration, extension, and enhancement. According to them, conjunctions mark relations where one span of text elaborates, extends or enhances another, an earlier span of text.

\section{RESEARCH METHOD}

This study employs descriptive qualitative design in which the source of data was selected abstracts of linguistics and literature theses written by undergraduate students of English Department in an Indonesian university produced in 2013-2015. There were totally 155 theses produced in those years, that the production in each year respectively was 56, 53, and 46. Among all the theses, the same number of linguistics and literature theses were selected. It is under the consideration that, in qualitative research, the researcher wants to ensure that she obtains a sample that is uniquely suited to the intention of the study (Fraenkel, Wallen, \& Hyun, 2012). The present study wants to scrutinize linguistics and literature thesis abstract. To facilitate the scrutiny, the same number of abstracts from both theses is required.

The same number of linguistics and literature theses was selected, that is, 15 abstracts each from linguistics and literature theses produced in 2013, 15 abstracts each from linguistics and literature theses produced in 2014, and 11 abstracts each from linguistics and literature theses produced in 2015. So there are 41 abstracts of 
linguistics theses and 41 abstracts of literature theses. The linguistics thesis abstracts are coded ling while the literature thesis abstracts are coded light. The full code of each thesis abstract is (year of publication)(linguistics or literature abstract)(sequence of the abstract). Thus there are 2013ling1-2013ling15, 2014ling1-2014ling15, 2015ling12015ling11, 2013lit1-2013lit15, 2014lit1-2014lit15, and 2015lit1-2015lit11.

The selected thesis abstracts are completely 82 . The remaining 73 thesis abstracts were not selected because they do not belong to either linguistics or literature theses. Although some of them belong to either linguistics or literature theses, they were still remained for gaining the same number of linguistics and literature thesis abstracts.

The data of the study is the conjunctions used in the abstracts of linguistics and literature theses written by undergraduate students of English Department. Thus the data is in the form of words or phrases expressing conjunctive relations in the abstracts.

Qualitative data are collected in the form of words or pictures rather than numbers (Fraenkel et al., 2012). This study uses documentation based on the written texts, that is, the selected thesis abstracts. The data of the study was obtained through the help of AntConc - a freeware corpus analysis toolkit for concordance and text analysis. Here AntConc was used to quickly find and mark the items serving as conjunctive relations on the basis of conjunctions taxonomy by Halliday and Matthiessen (2014). For instance, when a conjunctive item meanwhile was searched using AntConc, the result was in the following figure.

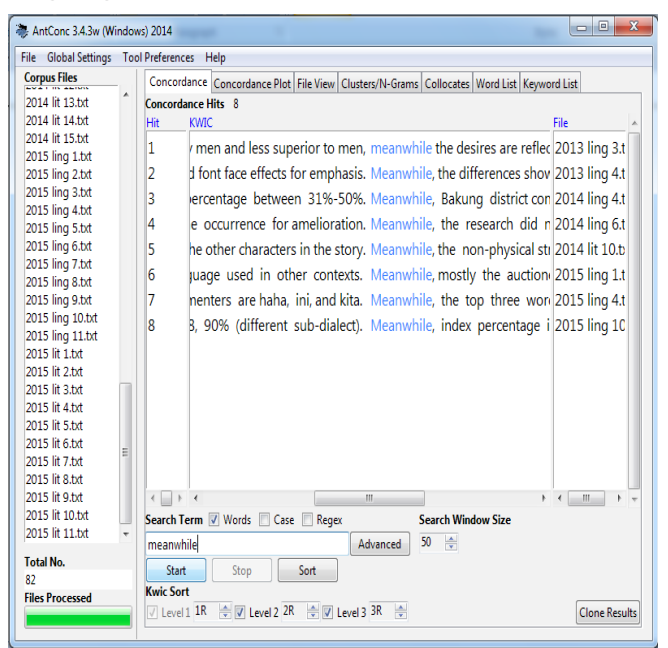

Figure 1. A search for a conjunctive item using AntConc

Figure 1 shows the frequency of conjunctive items meanwhile and in which thesis abstracts it was applied. After all, items serving as conjunctions were calculated, the results were summarized. In addition, close reading was done to annotate conjunctive relations.

A thorough analysis in qualitative research requires three steps: organization of the data, summarizing the data, and then interpreting the data (McMillan, 2008). The 
abstracts are analyzed by classifying and calculating the use of conjunctions using conjunctions taxonomy proposed by Halliday and Matthiessen (2014).

\section{FINDINGS AND DISCUSSIONS}

\section{Use of Conjunctions}

This subheading presents the findings of investigation of the conjunctions' use in abstracts of linguistics and literature theses written by undergraduate students of English Department. It explains, based on conjunctions theory proposed by Halliday and Matthiessen (2014), how conjunctions are used for organizing ideas in the abstracts and exposes whether or not they are appropriately used.

It is found that not all texts in the corpus, consisting of 41 abstracts of linguistics theses and 41 abstracts of literature theses, use conjunctions. There are six out of 82 thesis abstracts which do not apply conjunctions at all. They are four abstracts of linguistics theses and two abstracts of literature theses.

This implies that conjunction is not a must in composing abstracts. However, a device that connects clauses or sentences in a text is necessary. It is found that the writers of the six abstracts connected the ideas in their abstracts using words and/ or phrases which are excluded in conjunctions taxonomy proposed by Halliday and Matthiessen (2014). For example, in abstract 2013ling13, the writer used a phrase other than that to add information of the earlier sentence.

The other 37 abstracts of linguistics theses and the rest 39 abstracts of literature theses use the three types of conjunctions: elaboration, extension, and enhancement. Most subtypes of the three types are applied in both kinds of abstracts; namely clarifications, additions, variations, temporal, manners, and causal. While the opposition is only utilized in literature thesis abstract and matter in linguistics thesis abstract.

The two kinds of abstracts use conjunctions to cohesively link or bind their messages so that the transitions smooth and apparent. This supports a theory of conjunctions explaining that linking words and phrases can help a writer maintain flow and establish a clear relationship between ideas (Swales \& Feak, 1994).

\section{Appropriate Use of Conjunctions}

Some conjunctions are used appropriately and the others are used inappropriately. Elaborating conjunctions in linguistics and literature thesis abstracts are all used appropriately. Meanwhile, the use of extending and enhancing conjunctions in both kinds of abstracts are partly inappropriate. Some examples and the descriptions of how the conjunctions are used are as follows.

An example and explanation of the appropriate use of elaborating conjunction in linguistics thesis abstract are below. 
(1) The finding shows that there are some lexical differences found between the OPs (9). These differences also determine the status that emerges in Osing variety (10). From four OPs, this study has found 80 lexical differences from the total number of 450 glosses (11). The percentages that show dialect differences status are OP1:OP2 (48,75\%) with 39 lexical differences, OP1:OP4 $(38,75 \%)$ with 31 lexical differences, OP2:OP3 (48,75\%) with 39 lexical differences, and OP3:OP4 $(41,25 \%)$ with 33 lexical differences (12). The comparison between OP1: OP3 (52,50\%) with 42 lexical differences show dialect difference status (13). In conclusion, Osing as a regional variety has some variation in its lexical features which resulted in the emergence of different dialect and subdialects which are still mutually intelligible for the speakers (14). (2015ling9)

In excerpt (1), the phrase in conclusion in sentence 14 (S14) is used accurately to summarize the findings. After mentioning the findings in the previous sentences, S9-S13, the student drew a conclusion in the last sentence of her abstract, that is, S14.

An instance of the appropriate use of elaborating conjunction in literature thesis abstract is as follows.

(2) A person will always be a part of society and each and every society have its own set of rules and norms, and it is expected of the member of the societies to abide by those rules and norms (1). For example, a heteronormative society would promote heterosexuality as the correct way for people to be (2). (2015lit6)

The phrase, for example, an excerpt (2) functions to exemplify the prior information in the preceding sentence. It is accurately used in this abstract, as exemplification is a condition in which the second clause develops the thesis of the primary clause by becoming more specific about it, often citing an actual example (Halliday \& Matthiessen, 2014). Sentence 1 claims that a person should obey the rules and norms of where s/he lives. Sentence 2 illustrates it by giving a concrete example.

Below is an instance of the appropriate use of extending conjunction in linguistics thesis abstract.

(3) Lexical errors that deal with lexical aspect in writing become an important issue today since it has become the most numerous types of errors in learners' performance (1). Yet, there has been relatively little research about lexical errors (2). (2014ling11)

The conjunction yet in the excerpt (3) is very well applied. It is used to show an adversative relation between $\mathrm{S} 1$ and $\mathrm{S} 2$ in the abstract. The conjunction yet connects the sentence-lexical errors that deal with lexical aspect in writing become an important issue today, since it has become the most numerous types of errors in learners' performance-and-there has been relatively little research about the lexical errors. 
An example of the appropriate use of extending conjunction in abstract of literature thesis is as follows.

(4) This novel tells about the boy named Sam who wants to live in the wilderness because it offers the things that cannot be gotten in urban life and he wants to live closely with nature (3). (2014lit15)

The conjunction and in (4) succeeds to add a point to the previously mentioned information. It adds the reasons of why the boy named Sam wants to live in the wilderness. The first reason is it offers the things that cannot be gotten in urban life and the second reason is he wants to live closely with nature. So, the use of and in this instance is considered very well.

Below is an example of the appropriate use of enhancing conjunction in abstract of linguistics thesis.

(5) The data were collected by transcribing three episodes of Oprah Winfrey Show which had women as the guests and three episodes of Oprah Winfrey Show which had men as the guests (4). Then, the writer found each feature in the dialog and analyzed it using Lakoff's theory (5). (2015ling7)

The conjunction then is used to mark the temporal relation between data collection and data analysis in example (5). It is applied very well to describe the research methods.

An example of the appropriate use of enhancing conjunction in abstract of literature thesis is as follows.

(6) Thus, it is needed for a child to be nurtured and prepared to face the reality, so he or she will be able to survive in this life and cope with the problems ahead (3). (2014lit4)

The conjunction so in example (6) succeeds to create a cohesive relationship of causality between the clauses it binds. It can be seen that the clause introduced by so is the purpose of what has been mentioned before. The presence of $s o$ in between the clauses makes clear to readers, that the clause following so is purposive of what has been formerly mentioned.

\section{Inappropriate Use of Conjunctions}

Besides the appropriate uses of conjunctions that have been discussed previously, inappropriate uses of them are also found. That certain conjunctions are used inappropriately for organizing ideas in linguistics and literature thesis abstracts is, in general, the same as Cheng's (2014) finding. He found that Chinese students, particularly those majoring in computer science, showed difficulties in using conjunction when constructing abstracts. This shows that problems in applying conjunctions for composing abstracts are also encountered by English Department 
students. In addition, this is indeed closely akin to Hamed's (2014) finding which proved that learners of English as a foreign language (EFL) had difficulty in using conjunctions in their writing. The learners of EFL in his study were Libyan students and in this study were Indonesian students.

The undergraduate students of English Department who produced linguistics and literature thesis abstracts committed two inappropriate uses of conjunctions: misuse and overuse. Conjunctions which are used inappropriately in linguistics and/or literature thesis abstracts are extensions and enhancements. This means that Indonesian students' competence in English writing is not fully supported by their ability in using certain conjunctions.

The excerpt below shows misuse of extending conjunction in linguistics thesis abstract.

(7) The writer obtained that the participants used all politeness strategies cooperatively, but ustadzah used those strategies more than the parents because ustadzah's act caused more face threatening (7). (2015ling3)

The use of conjunction but an excerpt (7) is inappropriate because there is no adversative relation between the clauses before and after it. It can be seen that the clause following but does not work in opposition to the earlier clause. Rather, it is to elaborate it -providing more information, based on the earlier clause, about who used more politeness strategies among the participants in the study. Consequently, there is no adversative relation established between the clauses connected by but. If the conjunction but was simply changed by a phrase, for example, in which, S7 in abstract 2015ling3 would be more unified.

Misuse of extending conjunction in abstract of literature thesis is exemplified in the following.

(8) Racial discrimination is analyzed in this study since it remains to happen today particularly in an institution or it is usually called as institutionalized discrimination (1). (2013lit2)

The use of conjunction or in example (8) is not appropriate. It does not provide any alternative as alternative conjunction should do. The relation between the clauses before and after the conjunction or is elaboration rather than the alternation.

An instance and explanation of misuse of enhancing conjunction in abstract of linguistics thesis are below.

(9) Four sets of images that show humans and animals interactions are chosen as the object of analysis and it is found that the brochure offers a sense of 'responsibility' that can be done by visiting Taman Safari Prigen (3). At the same time, it implies that the wildlife is powerless and the safest place is when 
they are under humans' supervision (4). (2013ling10)

In excerpt (9), the conjunction at the same time is applied not so well for organizing ideas in the abstract. Careful examination of the whole excerpt helps to identify what relation the conjunction at the same time links or binds. In fact, it is used to link the relationship between the findings of the study. Its use became ambiguous since the earlier finding was presented together with the data (in S3), whereas the subsequent finding was presented in a separate sentence (S4).

Misuse of enhancing conjunction thus is illustrated by a literature thesis abstract below.

(10) This study concludes that the plot and character as the formal elements work together to support the theme "The Trusted Might Become The Traitor" of the novel (7). Thus, the study reveals the connection between the elements that create an organic unity as the main object of New Criticism (8). (2014lit1)

The conjunction thus applied in (10) fails to mark means relation in the excerpt. It is because the organization of the sentences is inaccurate. When S7 and S8 are carefully examined, it can be seen that their relation is inverted; S7 is by means of S8. If S8 is stated before S7 and they are connected by thus, the abstract would be more coherent.

From the preceding explanations, it can be seen that conjunctions which are used inappropriately in linguistics and/or literature thesis abstracts are extensions and enhancements. Of extending conjunctions, positive additives, adversatives, and alternatives were problematic for the students. Among enhancements, simple temporal, simple internal temporal, means, and general causal conjunctions were challenging for them. Similar findings are found in Hamed's (2014) study, in that Libyan students used the conjunctions - adversatives, additives, and causals - inappropriately in their writing. It is claimed that an inappropriate use of such conjunctions can be attributed to three reasons: 1) overgeneralization in the target language, which results from ignorance of rule restriction and incomplete application of rules, 2) the practice of presenting conjunctions in lists in ESL/EFL textbooks without showing the subtle differences between them in terms of semantic function, and 3) first language (Arabic) negative transfer. However, in this study, their reason for inappropriate use of these is because there is no special session to explicitly teach how to apply cohesive devices, in this case, conjunctions, in writing classes.

Another kind of inappropriate use of the conjunction is overuse. Some students seem to overuse conjunctions either to link or bind sentences in their thesis abstracts. Overuse of conjunctions is found in 12 abstracts: 2013ling4, 2014ling2, 2014ling4, 2014ling6, 2014ling11, 2014ling12, 2014ling14, 2015ling1, 2015ling2, 2015ling11, 2013lit7, and 2013lit12. See an example of overuses of conjunctions in the following excerpt. 
(11) The analysis of the data total of 399 lexical errors, with an average number of 10 errors per narrative writing (5). Besides, the analysis of the data showed was only 11 formal error and 3 sub-types of semantic error that occurred in the students' narrative writings (6). Moreover, calque most common lexical error with a total of 106 errors, followed by misselection which accounted for 84 near synonym which amounted to 52 errors (7). Furthermore, this study confirms that almost all of the student's serious problem in determining the correct form of lexical items (8). Therefore, this study suggest that vocabulary teaching and learning in English as a Second Language (ESL) or English as a Foreign Language (EFL) contexts and error correction during the teaching-learning process may become the alternative ways to help reduce the number of lexical errors that occur in the students' written compositions (9). (2014ling2)

Items serving as conjunctions are used frequently at the beginning of the last three sentences in example (11), that is, moreover, furthermore, and therefore. They are used in the initial sentence position to emphasize the ideas of each sentence. Yet their uses seem to be overuse because certain conjunction is used inappropriately and not every sentence needs conjunction. The conjunction furthermore in S8 should be substituted with summative conjunction, for example, in conclusion, for the reason that the sentence summarizes the findings of thesis 2014ling2. The conjunction therefore in S9 should be omitted because the sentence's topic is the same as the previous one, that is, about the study of 2014ling2.

Overuse of conjunctions indicates that the students' knowledge in applying conjunctions was mainly technical meaning, excluding semantic meaning. In addition, the overuse of conjunctions is performed more in linguistics thesis abstracts than in literature thesis abstracts. This implies that the writers of linguistics thesis emphasized cohesion, instead of coherence. They relied heavily on the connectedness of the messages in the abstracts, rather than the unity. It is suggested that they should have balanced the cohesion and coherence of their writing.

\section{Similarities of the Use of Conjunctions}

This subheading reveals the similarities in the ways conjunctions being used in abstracts of linguistics and literature theses written by undergraduate students of English Department. It is found that the use of conjunctions in linguistics and literature thesis abstracts is quite similar. The similarities are shown in the ways they are used and the total number of their uses. 
Table 1. Total number of conjunctions used in abstracts of linguistics and literature theses

\begin{tabular}{|c|c|c|c|c|c|}
\hline \multirow{10}{*}{$\begin{array}{l}\text { TYPE OF } \\
\text { EXP. } \\
\text { elaboration }\end{array}$} & \multicolumn{3}{|l|}{ Subtypes } & \multirow{2}{*}{$\begin{array}{l}\text { Linguistics } \\
-\end{array}$} & \multirow{2}{*}{$\begin{array}{l}\text { Literature } \\
-\end{array}$} \\
\hline & \multirow{2}{*}{$\begin{array}{l}\text { Subtypes } \\
\text { apposition }\end{array}$} & \multicolumn{2}{|l|}{ expository } & & \\
\hline & & \multicolumn{2}{|l|}{ exemplifying } & - & 1 \\
\hline & \multirow{7}{*}{ clarification } & \multicolumn{2}{|l|}{ corrective } & - & - \\
\hline & & \multicolumn{2}{|l|}{ distractive } & - & - \\
\hline & & \multicolumn{2}{|l|}{ dismissive } & - & - \\
\hline & & \multicolumn{2}{|l|}{ particularizing } & - & - \\
\hline & & \multicolumn{2}{|l|}{ resumptive } & - & - \\
\hline & & \multicolumn{2}{|l|}{ summative } & 2 & 1 \\
\hline & & \multicolumn{2}{|l|}{ verificative } & - & - \\
\hline \multirow[t]{6}{*}{ extension } & \multirow[t]{3}{*}{ addition } & \multicolumn{2}{|l|}{ positive } & 69 & 72 \\
\hline & & \multicolumn{2}{|l|}{ negative } & - & - \\
\hline & & \multicolumn{2}{|l|}{ adversative } & 15 & 13 \\
\hline & \multirow[t]{3}{*}{ variation } & \multicolumn{2}{|l|}{ replacive } & - & - \\
\hline & & \multicolumn{2}{|l|}{ subtractive } & - & - \\
\hline & & \multicolumn{2}{|l|}{ alternative } & 2 & 2 \\
\hline \multirow{27}{*}{ enhancement } & spatiotemporal: & simple & following & 12 & 2 \\
\hline & & & simultaneous & 1 & 1 \\
\hline & & & preceding & - & - \\
\hline & & & conclusive & 2 & 2 \\
\hline & & complex & immediate & - & - \\
\hline & & & interrupted & - & - \\
\hline & & & repetitive & - & - \\
\hline & & & specific & - & - \\
\hline & & & durative & 7 & 1 \\
\hline & & & terminal & - & - \\
\hline & & & punctiliar & - & - \\
\hline & & simple internal & following & 11 & 11 \\
\hline & & & simultaneous & - & - \\
\hline & & & preceding & - & - \\
\hline & & & conclusive & 1 & - \\
\hline & manner & comparison & positive & 2 & - \\
\hline & & & negative & - & - \\
\hline & & means & & 2 & 5 \\
\hline & causal- & general & & 4 & 10 \\
\hline & & specific & result & - & - \\
\hline & & & reason & - & - \\
\hline & & & purpose & - & - \\
\hline & & & $\begin{array}{l}\text { conditional: } \\
\text { positive }\end{array}$ & - & - \\
\hline & & & $\begin{array}{l}\text { conditional: } \\
\text { negative }\end{array}$ & - & - \\
\hline & & & concessive & - & - \\
\hline & matter & positive & & 1 & - \\
\hline & & negative & & - & - \\
\hline
\end{tabular}

In the ways conjunctions are used, both kinds of abstracts use some of them. In the level of types of conjunctions, both linguistics and literature thesis abstracts utilize elaborating, extending, and enhancing conjunctions. In the level of subtypes of conjunctions, both kinds of abstracts apply clarifications, additions, variations, temporal, manners, and causal. In the level of sub-subtypes of conjunctions, both linguistics and literature thesis abstracts use summative, positive additives, adversatives, alternatives, simple temporal, complex temporal, simple internal temporal, means, and general 
causal.

It is obvious that the use of conjunctions in linguistics and literature thesis abstracts is pretty similar. The two kinds of abstracts tend to use almost the same conjunctions to cohesively link or bind clauses or sentences. This all means that the writers of linguistics and literature theses had nearly the same ways to tie messages in their abstracts. This suggests that the students producing linguistics and literature theses had practically the same ways of writing abstracts. This also implies that students from a field of study, in this case, English Department, had the same discourses.

The similarities are also seen in the respect that either linguistics or literature thesis abstracts do not apply certain conjunctions. Conjunctions which are not used in either one of the two kinds of abstracts are found in the level of their sub-subtypes. Neither linguistics nor literature thesis abstracts use these following sub-subtypes of conjunctions: expository, corrective, distractive, dismissive, particularizing, resumptive, verificative, negative additive, replacive, subtractive, specific causal, and negative matter.

These conjunctions are not utilized by either one of the two kinds of abstracts because they express something that is not mentioned in the abstracts. In other words, they are not required to tie the abstracts' ideas. This is in line with Afful and Nartey's (2014) study claiming that the absence of certain conjunctions may be caused from students' unfamiliarity with the cohesive devices or simply because they were not needed in the texts. They also suggest that this is probably due to the nature of the genre under study and the topic of research since they notice how the abstract genre has the potential to influence the use of a cohesive element.

In terms of the total number of the use of conjunctions, it is found that the total number of the use of conjunctions in linguistics and literature thesis abstracts reaches almost the same. Elaborating conjunctions are employed each twice in linguistics and literature thesis abstracts. Extending conjunctions are used 86 times in abstracts of linguistics theses and 87 times in abstracts of literature theses. Enhancing conjunctions are applied 43 times in linguistics thesis abstracts and 32 times in literature thesis abstracts.

Both kinds of abstracts apply to extend conjunctions the most, followed by enhancing and elaborating ones. Of extending conjunctions, positive additive conjunctions appear to be the most frequently used cohesive device in both linguistics and literature thesis abstracts. This suggests that Indonesian students preferred explaining rather than debating. That is why they used much more positive additives than, for instance, adversatives and/or enhancing conjunctions. These findings are mirrored in previous studies, Zhang (2000) and Afful and Nartey (2014). Their studies found that conjunction is mostly used among the four grammatical cohesive devices and those additive conjunctions are most dominantly applied. The frequent use of conjunctions, in general, and additives, in particular, may stem from the writers' strong 
desire to explicitly itemize their points or advance their arguments chronologically (Afful \& Nartey, 2014).

Finally, there are more similarities than differences in the ways conjunctions being used by both linguistics and literature thesis abstracts. This finding confirms the previous study, which examined grammatical cohesion in Language and Literature abstracts of undergraduate dissertations, that similarities are much more evident than the differences (Afful \& Nartey, 2014). This is another proof that students from the same department of study shared the same discourses. The field of study of students in this study is the same as of students in Afful and Nartey's (2014) study, that is, English Department. Also, the finding corresponds to that of previous research, that is, Cheng (2014), that differences between the groups of subjects (computer science and linguistics) are not great. In the case of the current study, the groups of subjects are represented by linguistics and literature.

\section{CONCLUSIONS}

This study aims to investigate how conjunctions are used for organizing ideas in abstracts of linguistics and literature theses written by undergraduate students of English Department. It also aims to reveal the similarities in the ways conjunctions being used in the abstracts. In accomplishing the purposes, it uses conjunctions taxonomy proposed by Halliday and Matthiessen (2014) and employs descriptive qualitative design.

Based on the findings and discussions, the following conclusions are drawn. The use of conjunctions varies in terms of their appropriateness. Inappropriate uses of conjunctions show that applying conjunctions in writings was problematic for EFL learners. More particularly, using conjunctions for composing abstracts was challenging for Indonesian undergraduates of the English Department.

The students whose abstracts do not use conjunctions connected the messages in their abstracts using words and/or phrases which are excluded in the theoretical framework of this study. It is pointed out that conjunctions are required in writing abstracts, but not a must.

The similarities in the ways conjunctions being used by both linguistics and literature thesis abstracts are more than the differences. The two kinds of abstracts demonstrate similar ways in employing conjunctions and apply almost the same numbers of conjunctions. This emphasizes that the discourses of students from the same area, that is, the English Department, are the same.

At last, it may put forward some possibilities for future studies. A further study can arrange training for teaching the use of conjunctions in the Indonesian context and examine whether or not the students' ability in using conjunctions increase after the training. Similar studies can examine the use of conjunctions in abstracts of other disciplines or abstracts of graduates and postgraduates. Other studies can observe the 
use of conjunctions in the whole undergraduate theses, not only the abstracts. It is also possible to identify all types of cohesive devices in thesis abstracts.

\section{REFERENCES}

Afful, J. B. A., \& Nartey, M. (2014). Cohesion in the abstracts of undergraduate dissertations: An intra-disciplinary study in a Ghanaian university. Journal of ELT and Applied Linguistics (JELTAL), 2(1): 93-108.

Bailey, S. (2011). Academic writing: A handbook for international students (3rd ed.). London and New York: Routledge.

Cheng, F. (2014). Cohesive devices in English abstracts of MA theses by Chinese and occidental writers [Abstract]. Retrieved August 5, 2015, from http://www. globethesis.com/?t=2235330398968809

Fraenkel, J. R., Wallen, N. E., \& Hyun, H. H. (2012). How to design and evaluate research in education (8th ed.). New York: McGraw-Hill.

Halliday, M. A. K., \& Hasan, R. (1976). Cohesion in English. London: Longman.

Halliday, M. A. K., \& Matthiessen, C. M. I. M. (2014). Halliday's Introduction to functional grammar (4th ed.). Oxon: Routledge.

Hamed, M. (2014). Conjunctions in argumentative writing of Libyan tertiary students. Canadian Center of Science and Education, 7(3): 108-120.

Jeon, B., \& Eun, H. (2007). Contrastive rhetoric of doctoral dissertation abstracts written by American writers and Korean writers. The Linguistic Association of Korea Journal, 15(3), 161-188.

Ketabi, S., \& Jamalvand, A. A. (2012). A corpus-based study of conjunction devices in English international law texts and its Farsi translation. International Journal of Linguistics, 4(4), 362-371.

McMillan, J. H. (2008). Educational research: Fundamentals for the consumer (5th ed.). Boston: Pearson Education, Inc.

Paltridge, B. (2000). Making sense of discourse analysis. Queensland: Gold Coast.

Swales, J. M. (1990). Genre analysis: English in academic and research settings. Cambridge: Cambridge University Press.

Swales, J. M., \& Feak, C. B. (1994). Academic writing for graduate students: Essential tasks and skills. Michigan: The University of Michigan Press.

Zhang, M. (2000). Cohesive features in the expository writing of undergraduates in two Chinese universities. RELC Journal, 31(1), 61-95. 